МИНИСТЕРСТВО ОБРАЗОВАНИЯ И НАУКИ РОССИЙСКОЙ ФЕДЕРАЦИИ

СЕВЕРНЫЙ (АРКТИЧЕСКИЙ) ФЕДЕРАЛЬНЫЙ УНИВЕРСИТЕТ

ИМЕНИ М.В. ЛОМОНОСОВА

\author{
ИЗВЕСТИЯ \\ ВЫСШИХ УЧЕБНЫХ ЗАВЕДЕНИЙ
}

\title{
Десной журнал
}

\section{Научный журнал}

Основан в 1833 г.

Издается в серии ИВУЗ с 1958 г.

Выходит 6 раз в год

\section{$1 / 355$}

\section{7}

ИЗДАТЕЛЬ - СЕВЕРНЫЙ (АРКТИЧЕСКИЙ)

ФЕДЕРАЛЬНЫЙ УНИВЕРСИТЕТ ИМЕНИ М.В. ЛОМОНОСОВА 


\section{РЕДАКЦИОННАЯ КОЛЛЕГИЯ:}

МЕЛЕХОВ В.И. - гл. редактор, д-р техн. наук, проф. (Россия, Архангельск) БАБИЧ Н.А. - зам. гл. редактора, д-р с.-х. наук, проф. (Россия, Архангельск) БОГОЛИЦЫН К.Г. - зам. гл. редактора, д-р хим. наук, проф. (Россия, Архангельск) КОМАРОВА А.М. - отв. секретарь, канд. с.-Х. наук (Россия, Архангельск)

\section{ЧЛЕНЫ РЕДКОЛЛЕГИИ:}

Бессчетнов В.П., Д-р биол. наук, проф. (Россия, Нижний Новгород)

Богданович Н.И., д-р техн. наук, проф. (Россия, Архангельск)

Ван Хайнинген А., Д-р наук, проф. (США, Ороно)

Воронин А.В., д-р техн. наук, проф. (Россия, Петрозаводск)

Камусин А.А., д-р техн. наук, проф. (Россия, Москва)

Кищенко И.Т., д-р биол. наук, проф. (Россия, Петрозаводск)

Кожухов Н.И., Д-р экон. наук, проф., акад. РАН (Россия, Москва)

Куров В.С., д-р техн. наук, проф. (Россия, Санкт-Петербург)

Малыгин В.И., д-р техн. наук, проф. (Россия, Северодвинск)

Матвеева Р.Н., д-р с.-Х. наук, проф. (Россия, Красноярск)

Мерзленко М.Д., Д-р с.-х. наук, проф. (Россия, Москва)

Моисеев Н.А., д-р с.-х. наук, проф., акад. РАН (Россия, Москва)

Нимц П., д-р наук, проф. (Швейцария, Цюрих)

Обливин А.Н., д-р техн. наук, проф. (Россия, Москва)

Онегин В.И., Д-р техн. наук, проф. (Россия, Санкт-Петербург)

Памфилов Е.А., д-р техн. наук, проф. (Россия, Брянск)

Романов Е.М., д-р с.-х. наук, проф. (Россия, Йошкар-Ола)

Сакса Т., д-р с.-х. наук, ст. науч. сотр. (Финляндия, Хельсинки)

Санаев В.Г., д-р техн. наук, проф. (Россия, Москва)

Селиховкин А.В., д-р биол. наук, проф. (Россия, Санкт-Петербург)

Сергеевичев B.В., д-р техн. наук, проф. (Россия, Санкт-Петербург)

Сёренсен У.Я., проф. (Норвегия, Стейнхьер)

Сигурдссон Б.Д., Д-р наук, проф. (Исландия, Хваннейри)

Тараканов А.М., д-р с.-Х. наук, гл. науч. сотр. (Россия, Архангельск)

Усольцев В.А., д-р с.-х. наук, проф. (Россия, Екатеринбург)

Хакимова Ф.X., Д-р техн. наук, проф. (Россия, Пермь)

Холуша О., д-р наук, проф. (Чехия, Брно)

Черная Н.В., д-р техн. наук, проф. (Белоруссия, Минск)

Черных В.Л., д-р с.-х. наук, проф. (Россия, Йошкар-Ола)

Ширнин Ю.А., Д-р техн. наук, проф. (Россия, Йошкар-Ола)

Штукин С.С., д-р с.-х. наук, проф. (Белоруссия, Минск)

Энгельманн Х.-Д., Д-р инж. наук, проф. (Германия, Эмден)

\section{ЧЛЕНЫ РЕДАКЦИОННОГО СОВЕТА:}

Бабич Н.А. - председатель, д-р с.-х. наук, проф. (Россия, Архангельск) Билей П.В., д-р техн. наук, проф., акад. ЛАН Украины (Украина, Львов) Залесов С.В., Д-р с.-х. наук, проф. (Россия, Екатеринбург)

Мясищев Д.Г., Д-р техн. наук, проф. (Россия, Архангельск)

Наквасина Е.Н., Д-р с.-х. наук, проф. (Россия, Архангельск)

Хабаров Ю.Г., д-р хим. наук, проф. (Россия, Архангельск) 


\title{
BULLETIN
}

OF HIGHER EDUCATIONAL INSTITUTIONS

\section{Lesnoy Zhurnal \\ (Forestry journal)}

\section{Scientific journal}

Established in 1833

Issued as part of the

"Bulletin of Higher Educational Institutions" since 1958

Published 6 times a year

\section{$1 / 355$}

\author{
2017
}

PUBLISHER: NORTHERN (ARCTIC)

FEDERAL UNIVERSITY NAMED AFTER M.V. LOMONOSOV 


\section{EDITORIAL STAFF:}

MELEKHOV V.I. - Editor-in-Chief, Doctor of Engineering, Prof. (Russia, Arkhangelsk) BABICH N.A. - Deputy Editor-in-Chief, Doctor of Agriculture, Prof. (Russia, Arkhangelsk) BOGOLITSYN K.G. - Deputy Editor-in-Chief, Doctor of Chemistry, Prof. (Russia, Arkhangelsk)

KOMAROVA A.M. - Executive Secretary, Candidate of Agriculture (Russia, Arkhangelsk)

\section{MEMBERS OF THE EDITORIAL STAFF:}

Besschetnov V.P., Doctor of Biology, Prof. (Russia, Nizhny Novgorod)

Bogdanovich N.I., Doctor of Engineering, Prof. (Russia, Arkhangelsk)

Van Heiningen A., PhD, Prof. (USA, Orono)

Voronin A.V., Doctor of Engineering, Prof. (Russia, Petrozavodsk)

Kamusin A.A., Doctor of Engineering, Prof. (Russia, Moscow)

Kishchenko I.T., Doctor of Biology, Prof. (Russia, Petrozavodsk)

Kozhukhov N.I., Doctor of Economics, Prof., Member of the Russian Academy of Sciences (Russia, Moscow)

Kurov V.S., Doctor of Engineering, Prof. (Russia, Saint Petersburg)

Malygin V.I., Doctor of Engineering, Prof. (Russia, Severodvinsk)

Matveeva R.N., Doctor of Agriculture, Prof. (Russia, Krasnoyarsk)

Merzlenko M.D., Doctor of Agriculture, Prof. (Russia, Moscow)

Moiseev N.A., Doctor of Agricultural Sciences, Professor, Member of the Russian Academy of Sciences (Russia, Moscow)

Niemz P., PhD, Prof. (Switzerland, Zürich)

Oblivin A.N., Doctor of Engineering, Prof. (Russia, Moscow)

Onegin V.I., Doctor of Engineering, Prof. (Russia, Saint Petersburg)

Pamfilov E.A., Doctor of Engineering, Prof. (Russia, Bryansk)

Romanov E.M., Doctor of Agriculture, Prof. (Russia, Yoshkar-Ola)

Saksa T., Doctor of Agriculture, Senior Researcher (Finland, Helsinki)

Sanaev V.G., Doctor of Engineering, Prof. (Russia, Moscow)

Selikhovkin A.V., Doctor of Biology, Prof. (Russia, Saint Petersburg)

Sergeevichev V.V., Doctor of Engineering, Prof. (Russia, Saint Petersburg)

Sørensen O.J., PhD, Prof. (Norway, Steinkjer)

Sigurðsson B.D., PhD, Prof. (Iceland, Hvanneyri)

Tarakanov A.M., Doctor of Agriculture, Chief Research Scientist (Russia, Arkhangelsk)

Usol'tsev V.A., Doctor of Agriculture (Russia, Yekaterinburg)

Khakimova F.Kh., Doctor of Engineering, Prof. (Russia, Perm)

Holuša O., PhD, Prof. (Czech Republic, Brno)

Chernaya N.V., Doctor of Engineering, Prof. (Belarus, Minsk)

Chernykh V.L., Doctor of Agriculture, Prof. (Russia, Yoshkar-Ola)

Shirnin Yu.A., Doctor of Engineering, Prof. (Russia, Yoshkar-Ola)

Shtukin S.S., Doctor of Agriculture, Prof. (Belarus, Minsk)

Engelmann H.-D., Doctor of Engineering, Prof. (Germany, Emden)

\section{MEMBERS OF THE EDITORIAL BOARD:}

Babich N.A. - Chairman, Doctor of Agriculture, Prof. (Russia, Arkhangelsk)

Biley P.V., Doctor of Engineering, Prof., Member of the Forest Academy of Sciences of Ukraine (Ukraine, Lviv)

Zalesov S.V., Doctor of Agriculture, Prof. (Russia, Yekaterinburg)

Myasishchev D.G., Doctor of Engineering, Prof. (Russia, Arkhangelsk)

Nakvasina E.N., Doctor of Agriculture, Prof. (Russia, Arkhangelsk)

Khabarov Yu.G., Doctor of Chemistry, Prof. (Russia, Arkhangelsk) 
ISSN 0536 - 1036. ИВУ3. «Лесной журнал». 2017. № 1

\section{СОДЕРЖАНИЕ}

\section{ЛЕСНОЕ ХОЗЯЙСТВО}

П.Г. Мельник, Ю.Б. Глазунов, М.Д. Мерзленко. Рост и производительность архангельского климатипа сосны обыкновенной в условиях Подмосковья......

A.C. Новосёлов, Н.А. Дружинин. Сезонная динамика смолопродуктивности осушаемых сосновых древостоев.

X.M. Хетагуров. Возобновительный потенциал клена Траутфеттера в горных лесах Республики Северная Осетия-Алания.

T.B. Каштелян. Формирование системы воспроизводства лесных ресурсов Беларуси. ...

И.Т. Кищенко. Влияние климатических факторов на сезонный рост деревьев лиственных лесообразующих видов в таежной зоне................... 5

B.М. Ивонин, И.В. Воскобойникова. Рекреационная нагрузка и механическая эрозия на горных склонах в лесах Колхиды.

О.Н. Тюкавина, Д.Н. Клевиов, Н.А. Бабич. Черты сходства динамики длины хвои по годам роста сосны обыкновенной в различных условиях произрастания...

О.И. Антонов. Повышение качественной продуктивности насаждений - задача

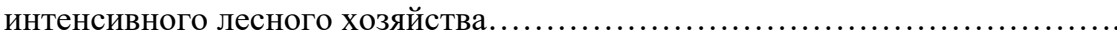

A.С. Ильиниев, С.В. Третьяков, Р.А. Ершов, И.В. Федотов. Влияние добровольно-выборочных рубок на текущий прирост древесины в высоковозрастных

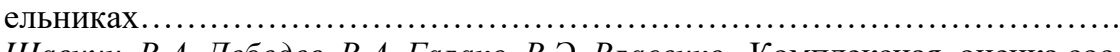

С.А. Шавнин, В.А. Лебедев, В.А. Галако, В.Э. Власенко. Комплексная оценка состояния лесных генетических резерватов Свердловской области с помощью методов дистанционного и наземного обследования.

\section{ЛЕСОЭКСПЛУАТАЦИЯ}

А.С. Торопов, А.Н. Заикин, В.М. Меркелов. Особенности переработки древесины, загрязненной радионуклидами.

Д.Г. Мясищев, С.А. Путинщеев. Оптимизация расхода топлива роторного измель-

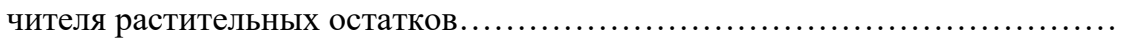

C.B. Посыпанов. Определение геометрических параметров плавающего транспортного пакета круглых лесоматериалов численным методом. ... 
ISSN 0536 - 1036. ИВУ3. «Лесной журнал». 2017. № 1

МЕХАНИЧЕСКАЯ ОБРАБОТКА ДРЕВЕСИНЫ

И ДРЕВЕСИНОВЕДЕНИЕ

С.П. Агеев. Нормирование электроэнергии, потребляемой лесопильными рамами

Ф.В. Черепенин, С.М. Сковпень, Д.А. Ульяничев. Цифровое моделирование при обработке литейных моделей из древесины и древесных материалов на станках токарной группы.

ХИМИЧЕСКАЯ ПЕРЕРАБОТКА ДРЕВЕСИНЫ

Е.С. Тюрмина, И.С. Ильичев, А.Б. Радбиль, Л.Л. Семенычева, М.А. Лазарев, E.A. Маврина, А.А. Шалашова. Очистка сульфатного скипидара-сырца от серасодержащих соединений.

О.С. Бровко, И.А. Паламарчук, Н.В. Сысоева, Н.А. Вальчук, Т.А. Бойцуова, К.Г. Боголищыл, В.К. Дубовый. Фильтрующие материалы на основе минеральных волокон с биополимерным слоем. ... 


\section{FORESTRY}

P.G. Mel'nik, Yu.B. Glazunov, M.D. Merzlenko. The Growth and Productive Capacity of the Arkhangelsk Climatype of Scots Pine in the Moscow Region.

A.S. Novoselov, N.A. Druzhinin. Seasonal Resin Productivity Dynamics of Drained Pine Stands.

Kh.M. Khetagurov. Trautvetter's Maple Regeneration Potential in the Mountain Forests of the Republic of North Ossetia-Alania................................. 30

T.V. Kashtelyan. Formation of the Forest Regeneration System of Belarus............ 40

I.T. Kishchenko. The Impact of Climatic Factors on the Seasonal Growth of Deciduous Trees of the Forest-Forming Species in the Taiga Zone.

V.M. Ivonin, I.V. Voskoboynikova. Recreational Load and Mechanical Erosion on the Mountainsides in the Forests of Colchis................................... 64

O.N. Tyukavina, D.N. Klevtsov, N.A. Babich. The Similarity of the Needle Length Dynamics on an Annual Basis of Scots Pine Growth in Different Conditions......

O.I. Antonov. Qualitative Productivization of Forest Stands is the Goal of Intensive Forestry ..........................................................

A.S. Il'intsev, S.V. Tret'yakov, R.A. Ershov, I.V. Fedotov. The Effect of VoluntarySelective Felling on the Basic Wood Increment in the Aged Spruce Forests.......

S.A. Shavnin, V.A. Lebedev, V.A. Galako, V.E. Vlasenko Integrated Assessment of Forest Genetic Reserves of the Sverdlovsk Region by the Methods of Remote and Ground Survey

\section{WOOD EXPLOITATION}

A.S. Toropov, A.N. Zaikin, V.M. Merkelov. Peculiarities of Processing of Wood 119 Polluted by Radioactive Nuclides

D.G. Myasishchev, S.A. Putintsev. Fuel Optimization of a Rotary Chopper for Plant Residues.

S.V. Posypanov. Numerical Determination of the Geometric Parameters of a Transport Floating Roundwood Bundle.

\section{MECHANICAL TECHNOLOGY OF WOOD AND WOOD SCIENCE}

S.P. Ageev. Rationing of Electricity Consumed by Saw Frames...

F.V. Cherepenin, S.M. Skovpen', D.A. Ul'yanichev. Digital Simulation when Wood and Wood-Based Materials Casting Patterns Processing on the Turning Lathes 


\section{CHEMICAL TECHNOLOGY OF WOOD}

E.S. Tyurmina, I.S. Il'ichev, A.B. Radbil', L.L. Semenycheva, M.A. Lazarev, E.A. Mavrina, A.A. Shalashova. The Raw Sulfate Turpentine Purification from Sulfur-Containing Compounds..............................................
Brovko, I.A. Palamarchuk, N.V. Sysoeva, N.A Val'chuk, T.A. Boytsova,

O.S. Brovko, I.A. Palamarchuk, N.V. Sysoeva, N.A Val'chuk, T.A. Boytsova,
K.G. Bogolitsyn, V.K. Dubovyy. Filter Materials Based on Mineral Fibers with Biopolymer Layer.............................................. 186 